\title{
Growth and Acidification by Vaginal Lactobacilli in Anaerobic Liquid Medium Over the pH Range 5.5 - 8.0
}

\author{
Michelle Angela Graver and Jeremy James Wade* \\ Medical Microbiology, King's College Hospital, Denmark Hill, London, SE5 9RS
}

\begin{abstract}
We studied the growth of three vaginal lactobacilli in a defined liquid medium under anaerobic conditions across the $\mathrm{pH}$ range $5.5-8.0$. Growth and acidification profiles of the lactobacilli varied significantly. This model could aid the selection of strains - or combinations of strains - with probiotic potential.
\end{abstract}

The flora of the healthy vagina is simple and usually dominated by one or a few species of lactobacilli (LB) $[7,10]$. LB maintains the acidity of the vagina and are critical for vaginal health. Bacterial vaginosis (BV) is the most prevalent vaginal syndrome with major public health implications worldwide [6] and is characterized by a depletion of vaginal $\mathrm{LB}$. Recurrence of BV is seen in approximately $30 \%$ of affected females and LB-containing probiotic preparations have been evaluated for treatment and prevention. A means of quantifying the growth and acidification potential of $\mathrm{LB}$ over a range of $\mathrm{pH}$ values would be useful for intra- and inter-species comparisons of LB considered as potential probiotic candidates. To address this, we studied three vaginal LB under anaerobic conditions in liquid medium over a range of pHs.

A defined liquid medium rendered anaerobic with 'Oxyrase for Broth' (Oxyrase Inc, Ohio, USA) was prepared and used as described previously [11] at initial pHs 5.5, 6.0, 6.5, 7.0, 7.5 and 8.0. In brief, media with and without buffer - and for each of these, with and without $1.25 \mathrm{~g} / \mathrm{L}$ human hemoglobin $(\mathrm{Hb})$ - were adjusted to the required initial $\mathrm{pH}$ using $1 \mathrm{M} \mathrm{HCl}$ before filter sterilizing through a $0.22 \mu \mathrm{m}$ filter. The buffers used were 30mM MES for $\mathrm{pH} 5.5-6.5$ and $30 \mathrm{mM}$ MOPS for $\mathrm{pH} 7.0-8.0$. Media were pre-reduced in $7 \mathrm{~mL}$ screwtop plastic bijoux (Bibby Sterilin) by incubation at $37^{\circ} \mathrm{C}$ for at least $2 \mathrm{~h}$ before inoculation [11]. Suspensions of Lactobacillus crispatus NCTC 4505 (LC), Lactobacillus gasseri ATCC 9857 (LG), Lactobacillus jensenii ATCC 25258 (LJ) and Fusobacterium nucleatum ATCC 25586 (FN) in phosphate-buffered saline (PBS) were prepared such that 100 - $200 \mu \mathrm{L}$ added to $7 \mathrm{~mL}$ of medium gave $\approx 10^{4} \mathrm{cfu} / \mathrm{mL}$. Controls for each medium at each initial $\mathrm{pH}$ included: uninoculated media to measure the $\mathrm{pH}$ effect of Oxyrase; rezasurin sodium at $0.002 \mathrm{~g} / \mathrm{L}$ as a reduction indicator; and FN to demonstrate ability to support anaerobic growth. Also, each strain was inoculated in to MES- and MOPS-containing media adjusted to $\mathrm{pH} 6.6$ - which is at the overlap of the buffers' ranges - to identify any potential inhibition by the buffers. To provide growth curves for each strain in unbuffered medium, each was inoculated in to medium without buffer adjusted to $\mathrm{pH}$ 6.6. Bijoux were incubated statically at $37^{\circ} \mathrm{C}$ and counts done after vortexing for 5 s on an undiluted aliquot and serial $10^{-1}$ dilutions in PBS on blood agar (Oxoid, UK) using a spiral plater (Don Whitley, Shipley, UK) at inoculation and at $25 \mathrm{~h}$, at which time $\mathrm{pH}$ was measured. For growth curves, additional samples were taken at $15 \mathrm{~h}$ and $20 \mathrm{~h}$. Plates were incubated in $5 \% \mathrm{CO}_{2}$ for 24 - $48 \mathrm{~h}$ for $\mathrm{LB}$ and in anaerobic jars for $48 \mathrm{~h}$ for FN. All chemicals were from Sigma, Poole, UK and all experiments done at least in triplicate. The $\log _{10} \mathrm{cfu} / \mathrm{mL}$ change in colony counts between time 0 and $25 \mathrm{~h}$ were calculated for all medium-bacterium combinations and the $\mathrm{pH}$ change over $25 \mathrm{~h}$ calculated using the uninoculated Oxyrase-containing control as baseline. For each strain the Wilcoxon Rank-sum test was used to compare the $\log _{10} \mathrm{cfu} / \mathrm{mL}$ changes in MES at pH 6.6 with those in MOPS at pH 6.6.
At each initial $\mathrm{pH}$, resazurin controls indicated reduction at inoculation and up to $25 \mathrm{~h}$. In medium without $\mathrm{Hb}$ at inital $\mathrm{pH} 5.5$ Oxyrase alone increased $\mathrm{pH}$ by median $0.30 \mathrm{pH}$ points with and 0.83 without, buffer. This alkalinization at low initial $\mathrm{pH}$ reduced steadily to negligible for media at initial $\mathrm{pH} 7.5$; for the $\mathrm{pH} 8.0$ media there was minimal acidification (median decrease of $0.13 \mathrm{pH}$ points with and 0.31 without, buffer); almost identical results were seen in the presence of $\mathrm{Hb}$. Each strain grew in unbuffered medium (Figure 1). For each bacterium, growth from initial pH 6.6 in MES did not differ significantly from that in MOPS $(\mathrm{P}=0.13$ to $\mathrm{P}=1.00)$. FN grew in all media with median increase in $\log _{10} \mathrm{cfu} / \mathrm{mL}$ of 4.48 at $\mathrm{pH} 6.0$ reducing to 2.93 at $\mathrm{pH}$ 8.0. However, at $\mathrm{pH} 5.5$ the $\log _{10} \mathrm{cfu} / \mathrm{mL}$ increase with buffer (with $\mathrm{Hb}: 1.3$, without $\mathrm{Hb}: 2.3$ ) was substantially less than without buffer (4.04 and 4.72, respectively) (Figure 2).

Growth and acidification profiles of the LB varied significantly across the range of initial pHs (Figure 3). Of the three LB, only LC was capable of growing across the whole range, though growth

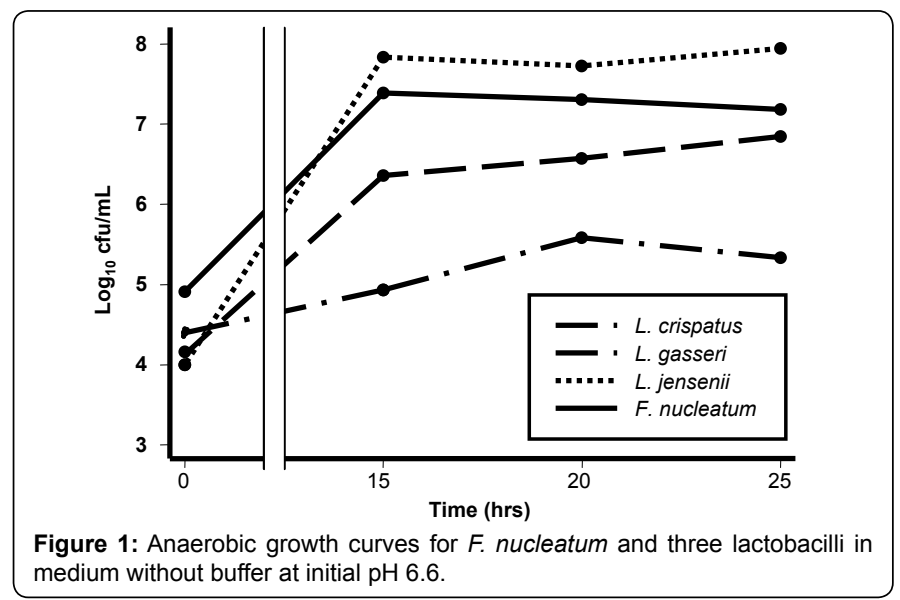

*Corresponding author: Jeremy James Wade MD FRCPath, Medical Microbiology, King's College Hospital, Denmark Hill, London SE5 9RS, Tel: +44 203 2993033; Fax: +44 203 2993404; E-mail: ïwade@nhs.net

Received August 25, 2010; Accepted October 28, 2010; Published October 30, 2010

Citation: Graver MA, Wade JJ (2010) Growth and Acidification by Vaginal Lactobacilli in Anaerobic Liquid Medium Over the pH Range 5.5-8.0. J Bacteriol Parasitol 1:102. doi:10.4172/2155-9597.1000102

Copyright: (c) 2010 Graver MA, et al. This is an open-access article distributed under the terms of the Creative Commons Attribution License, which permits unrestricted use, distribution, and reproduction in any medium, provided the original author and source are credited. 

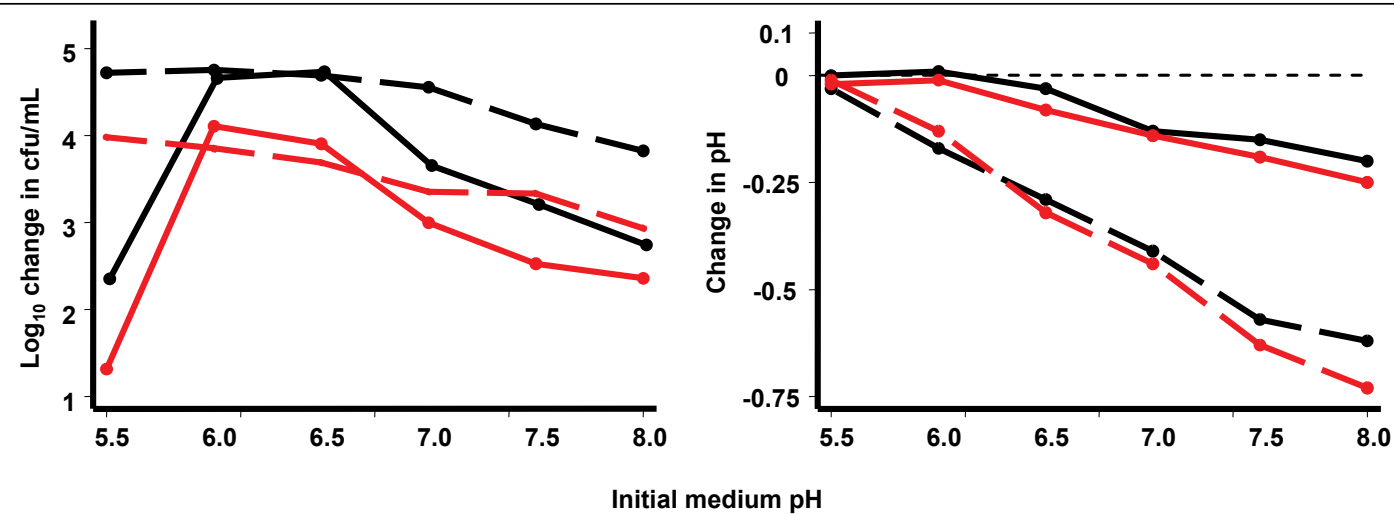

Figure 2: Change in bacterial counts and $\mathrm{pH}$ for $F$. nucleatum after $25 \mathrm{~h}$ of anaerobic incubation with or without haemoglobin (red and black lines, respectively) and with or without MES buffer (intact and dotted lines, respectively)

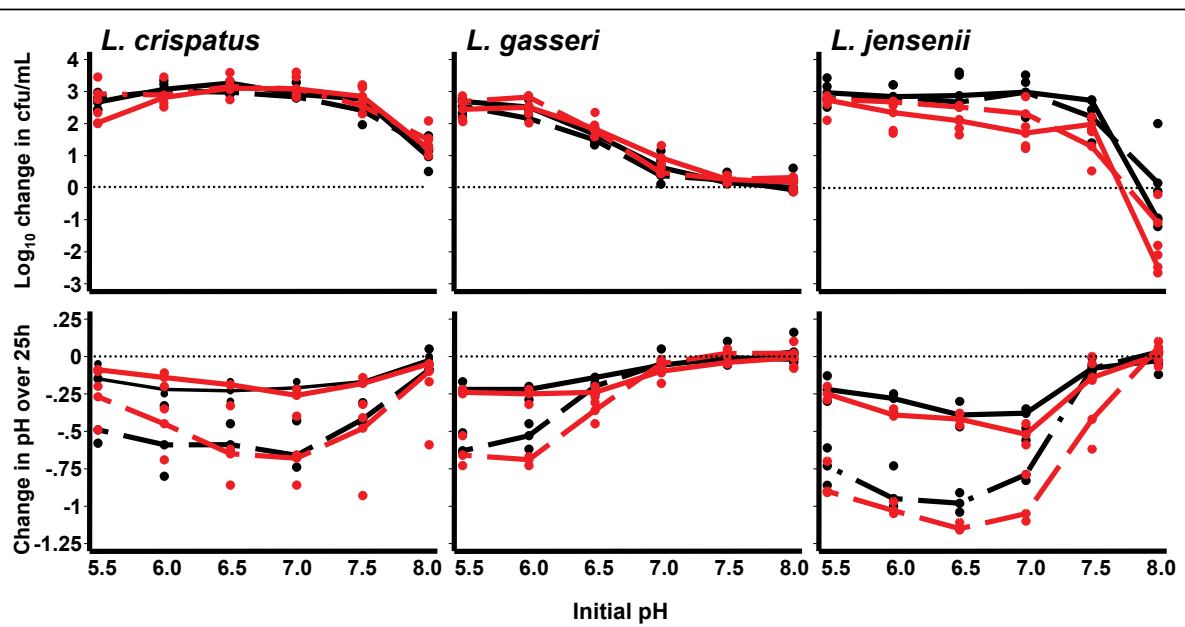

Figure 3: Change in bacterial counts and $\mathrm{pH}$ after 25h of anaerobic incubation for three lactobacilli, with or without haemoglobin (red \& black lines, respectively), and with or without MES buffer (intact and dotted lines, respectively).

was optimal from pHs 6.0 - 7.5; acidification was maximal from initial pH 6.5 - 7.0, but negligible from initial $\mathrm{pH}$ 8.0. LG growth and acidification were maximal when initial $\mathrm{pH}$ was 5.5 or 6.0 , falling to negligible when $\geq 7.0$. Growth of $\mathrm{LJ}$ was consistent when initial $\mathrm{pH}$ was $5.5-7.5$, but reduced by $\mathrm{Hb}$ and inhibited markedly at initial $\mathrm{pH}$ 8.0; $\mathrm{LJ}$ was the most potent acidifier at initial $\mathrm{pH}<7.0$ but this was reduced when initial $\mathrm{pH}$ was $>7.0$.

To reduce any unpredictable buffering effects of standard nutrient broths we used a defined medium with limited inherent buffering capacity and very low concentrations of complex organic substrates. The lower end of the $\mathrm{pH}$ range we used is more acidic than the $\mathrm{pH}$ range recommended by the manufacturer of Oxyrase ( $\mathrm{pH} 6.8-8.4)$, but the resazurin indicator and growth of FN confirmed anaerobiosis throughout. Indeed the growth of FN was maximum at the lowest $\mathrm{pH}$ values. We assume that the reduced growth of FN at initial pH 5.5 in MES, compared with no buffer, may reflect the anaerobe's inability in the presence of buffer to elevate $\mathrm{pH}$ to permit optimum growth. This is most likely to be a FN-specific $\mathrm{pH}$ effect rather than a failure to achieve anaerobiosis: a greater than ten-fold increase in recoverable $\mathrm{cfu} / \mathrm{mL}$ was still achieved in the presence of buffer.

We included a fixed molarity of each buffer to permit a crude assessment of the magnitude of $\mathrm{pH}$ change generated. No significant differences with respect to growth rate in MES or MOPS were identified. Using both buffers permitted an extended $\mathrm{pH}$ range encompassing that of the normal vagina and the more alkaline conditions found in BV. We chose the single sampling point at $25 \mathrm{~h}$ as preliminary experiments (results not shown) indicated that growth of LB in the basal medium was maximal at 20 - 25h without evidence of a rapid decline in viability thereafter. Although we included $\mathrm{Hb}$ in an attempt to mimic menses, the $\mathrm{Hb}$ concentration used was the highest compatible with filter sterilization; heat sterilization may have altered the properties of the medium and reduced reproducibility. Although this concentration of hemoglobin is presumably lower than that achieved in the vagina mid-menses, it did adversely affect the growth of LJ.

Typically $60-95 \%$ of healthy women harbor LB in the vagina at counts of $10^{7}-10^{9} \mathrm{cfu} / \mathrm{gm}$ secretions. LC and $\mathrm{LJ}$ predominate in the normal vagina and an LC-predominant flora may represent a stable flora [5]; the importance of $\mathrm{LG}$ is less clear. $\mathrm{LB}$ are thought to protect the female genital tract primarily by maintaining a low $\mathrm{pH}$ through metabolism of oestrogen-stimulated glycogen in shed epithelial cells. Certainly, LB are capable of generating and surviving very low $\mathrm{pH}$ environments in vitro [2] and most vaginal lactic acid is of the D-lactate isomer and therefore of bacterial and not human origin [3]. LB may also inhibit opportunist bacteria through the production of bacteriocins, immune stimulation and via nutrient and stearic competition. There is also substantial interest in the role of hydrogen peroxide $\left(\mathrm{H}_{2} \mathrm{O}_{2}\right)$ production by LB. The lowest prevalence of BV is seen in those colonized both vaginally and rectally by $\mathrm{H}_{2} \mathrm{O}_{2}$-producing $\mathrm{LB}$; colonization at either site is more protective than colonization at neither [1]. 
Citation: Graver MA, Wade JJ (2010) Growth and Acidification by Vaginal Lactobacilli in Anaerobic Liquid Medium Over the pH Range 5.5 - 8.0. J Bacteriol Parasitol 1:102. doi:10.4172/2155-9597.1000102

Page 3 of 3

The normal vagina has a $\mathrm{pH}$ of $3.5-6.0[4]$ and is anaerobic, with $\mathrm{pO}_{2}$ and $\mathrm{pCO}_{2}$ lower and higher, respectively, than atmospheric levels; menstruation increases $\mathrm{pH}[9,12]$ and oxygen tension [8]. Studies of LB characteristics that may protect the vagina should address these conditions. Although we used just one strain each of the three major species - and could not achieve the lowest $\mathrm{pH}$ of the healthy vagina with our buffers - the differences in growth and acidification profiles across the $\mathrm{pH}$ range suggest that this simple model could be used to evaluate other LB characteristics deemed important for vaginal health. For example, our results indicate that the LC strain used may survive the alkaline and anaerobic conditions of incipient BV whilst still acidifying. In contrast, the $\mathrm{LJ}$, whilst offering substantial acidification at lower $\mathrm{pH}$ values, may succumb as the $\mathrm{pH}$ of the vagina increases. By identifying strain or species differences this model could facilitate selection of strains - or combinations of strains - with probiotic potential.

\section{References}

1. Antonio MA, Rabe LK, Hillier SL (2005) Colonization of the rectum by Lactobacillus species and decreased risk of bacterial vaginosis. J Infect Dis 192: 394-398.

2. Boskey ER, Telsch KM, Whaley KJ, Moench TR, Cone RA (1999) Acid production by vaginal flora in vitro is consistent with the rate and extent of vaginal acidification. Infect Immun 67: 5170-5175.

3. Boskey ER, Cone RA, Whaley KJ, Moench TR (2001) Origins of vaginal acidity: high $\mathrm{D} / \mathrm{L}$ lactate ratio consistent with bacteria being the primary source. Hum Reprod 16: 1809-1813.

4. Chen KCS, Forsyth PS, Buchanan TM, Holmes KK (1979) Amine content of vaginal fluid from untreated and treated patients with non-specific vaginitis. J Clin Invest 63: 828-835.

5. Ferris MJ, Norori J, Zozaya-Hinchlioffe M, Martin DH (2007) Cultivationindependent analysis of changes in bacterial vaginosis flora following metronidazole therapy. J Clin Microbiol 45: 1016-1018.

6. Fethers KA, Fairley CK, Hocking JS, Gurrin LC, Bradshaw CS (2008) Sexual risk factors and bacterial vaginosis: a systematic review and meta-analysis. Clin Infect Dis 47: 1426-1435.

7. Fredricks DN, Fiedler TL, Marrazzo JM (2005) Molecular identification of bacteria associated with bacterial vaginosis. N Engl J Med 353: 1899-1911.

8. Hill DR, Brunner ME, Schmitz DC, Davis CC, Flood JA, et al.(2005) In vivo assessment of human vaginal oxygen and carbon dioxide levels during and post menses. J Appl Physiol 99: 1582-1591.

9. Johnson SR, Petzold CR, Galask RP (1985) Qualitative and quantitative changes of the vaginal microbial flora during the menstrual cycle. Am J Reprod Immunol Microbiol 9: 1-5.

10. Ravel J, Gajer P, Abdo z, Schneider GM, Koenig SS, et al. (2010) Microbes and Health Sackler Colloquium:Vaginal microbiome of reproductive-age women. Proc Natl Acad Sci USA.

11. Wade JJ, Graver MA (2009) A liquid medium permitting anaerobic growth of Neisseria gonorrhoeae. J Microbiol Methods 79: 364-366.

12. Wilks M, Tabaqchali S (1987) Quantitative bacteriology of the vaginal flora during the menstrual cycle. J Med Microbiol 24: 241-245. 